\title{
OPTIMIZATION OF ASPERGILLUS ORYZAE FERMENTATION CONDITIONS FOR KOJIC ACID PRODUCTION
}

\author{
ADNINA FITRA AZZAHRA, DYAH KARINA PUSPITA SUKARNA, HERMAN SURYADI* \\ Laboratory of Microbiology and Biotechnology, Faculty of Pharmacy, Universitas Indonesia, Depok 16424, Indonesia. \\ Email: hsuryadi@farmasi.ui.ac.id
}

Received: 07 June 2018, Revised and Accepted: 27 September 2018

\section{ABSTRACT}

Objective: The objective of this study is to obtain the optimal fermentation conditions for Aspergillus oryzae by gradually optimizing the medium and fermentation conditions.

Methods: Fermentation condition were optimized by varying carbon and nitrogen sources, pH medium, temperature, and aeration condition. Levels of kojic acid were determined using thin-layer chromatography-densitometry with an ultraviolet detector at a wavelength of 318 nm.

Results: A combination of sucrose and yeast extract was chosen as the best source of carbon and nitrogen, respectively, from nine medium variations, producing $1.5425 \mathrm{~g} / \mathrm{L}$ kojic acid. The optimum acidity of the medium was at $\mathrm{pH} 4.5$, producing $1.7127 \mathrm{~g} / \mathrm{L} \mathrm{of} \mathrm{kojic} \mathrm{acid,} \mathrm{compared} \mathrm{with} \mathrm{pH} 3.5$ and 5.5. Compared with fermentation at room temperature, fermentation at $35^{\circ} \mathrm{C}$ yielded greater kojic acid production. The best aeration condition was $100 \mathrm{~mL}$ medium in $250 \mathrm{~mL}$ flask that produced the most kojic acid $(1.6472 \mathrm{~g} / \mathrm{L})$

Conclusion: The optimal medium for fermentation of kojic acid using A. oryzae uses sucrose and yeast extract as carbon and nitrogen sources, respectively, at $\mathrm{pH} 4.5$. The optimal aeration and incubation conditions were used, a volume of $100 \mathrm{~mL}$ in a $250 \mathrm{~mL}$ conical flask, incubated at $35^{\circ} \mathrm{C}$, obtaining the highest yield value of $0.0370 \mathrm{~g} / \mathrm{g}$.

Keywords: Aspergillus oryzae, Fermentation, Kojic acid, Optimization.

(C) 2018 The Authors. Published by Innovare Academic Sciences Pvt Ltd. This is an open access article under the CC BY license (http://creativecommons. org/licenses/by/4. 0/) DOI: http://dx.doi.org/10.22159/ijap.2018.v10s1.70

\section{INTRODUCTION}

Kojic acid is an organic acid with many uses, such as antibacterial, antifungal, anti-melanosis, and a chelating agent. It can be applied in areas such as chemistry, health, food, and cosmetics; however, it, currently, has limited commercial use despite the market being developed 40 years ago. The recent development of industries related to the application of these compounds, especially in the field of cosmetics, has fueled an increased interest in kojic acid [1].

Kojic acid is produced biologically by various microorganisms, including species of Aspergillus and Penicillium, and involves aerobic fermentation using various substrates. Kojic acid-producing microorganisms, such as Aspergillus oryzae, Aspergillus flavus, Aspergillus tamarii, and Aspergillus parasiticus are reported to produce high levels of kojic acid [1-5].

A. oryzae is a filamentous fungus, or mold, well known in Indonesia. The use of this microorganism is not novel, and reports of soy sauce, one of its fermentation products, date back to 1680 [6]. Other common uses of A. oryzae in Indonesia include the manufacture of tauco [7].

The development of kojic acid fermentation has generally focused on genetic mutations to produce new strains or optimization of factors affecting fermentation [1]. Kojic acid fermentation itself is influenced by several factors, such as carbon and nitrogen sources as substrates, $\mathrm{pH}$, temperature, aeration, and agitation [2].

The present study optimized each factor individually. First, the fermentation medium was optimized, focusing on carbon and nitrogen sources, and $\mathrm{pH}$. Next, aeration and incubation temperature were optimized. Then, the fermentation results were analyzed by spectrophotometry to determine the remaining sugar content. The optimum conditions were determined through culture analysis using thin-layer chromatography (TLC)-densitometry to measure the levels of kojic acid produced by each variable. To strengthen our results, previously reported methods of analysis were used [8-10].

\section{METHODS}

Medium Rejuvenation, Medium Preculture/Inoculum Development containing $1 \%$ yeast extract and $5 \%$ technical sucrose, and medium fermentation phase optimization, containing a $5 \%$ carbon source, $0.25 \%$ variation of nitrogen source, $0.05 \% \mathrm{MgSO}_{4}$, and $0.1 \% \mathrm{KH}_{2} \mathrm{PO}_{4}$ were used to prepare the media. Table 1 shows the variations of carbon and nitrogen sources. Verification of the kojic acid analysis method using TLCdensitometry was performed by generating an absorption curve, kojic acid calibration curve, and an accuracy and precision test. The optimization of the fermentation medium focused on optimizing the carbon and nitrogen sources, as well as the $\mathrm{pH}$. The results obtained were based on the growth of cell biomass and the resulting kojic acid levels. Optimization of the fermentation conditions was performed by optimizing the aeration and incubation temperature. The results obtained were based on the growth of cell biomass and the resulting kojic acid levels. Quantitative analysis of the fermentation culture was performed. The dry cell weight method was used to analyze the cell biomass. Finally, the sugar content in the fermentation filtrate was determined.

\section{RESULTS AND DISCUSSION}

Results

Rejuvenation and inoculum preparation

After rejuvenation using potato dextrose agar (PDA) medium in tilted, screw-capped tubes for 7 days, a culture of dark green mold on the jelly surface was obtained. The newly rejuvenated mold was white for the first few day (Fig. 1). To multiply the cells and prepare the formed biomass for the fermentation stage, preculture was performed. 
After incubation for $24 \mathrm{~h}$ at $180 \mathrm{rpm}$, it was produced mold cell culture in the form of pellets that are yellowish white in color (Fig. 2). Throughout the study, several schemes were performed for each fermentation condition.

Verification of kojic acid analysis method using TLC-densitometry Absorption curve

TLC-densitometry requires that the maximum wavelength of the compound to be analyzed is known. This was determined by analyzing a solution of $100 \mu \mathrm{g} / \mathrm{mL}$ kojic acid at a wavelength of 200-400 nm. The maximum wavelength was found to be $318 \mathrm{~nm}$ and was used for subsequent analyzes of kojic acid using TLC-densitometry.

\section{Calibration curve and linearity}

After the maximum wavelength was determined, a calibration curve was generated using various concentrations of kojic acid to obtain the

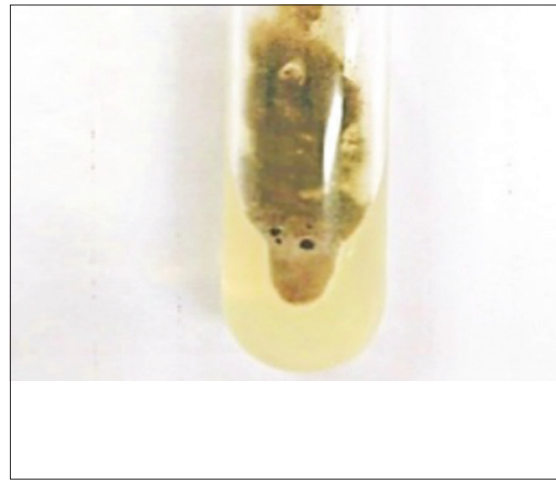

Fig. 1: Aspergillus oryzae culture colony in tilted potato dextrose agar medium after 7 days

Table 1: Variations of carbon sources and nitrogen source used in the optimization stage

\begin{tabular}{ll}
\hline Carbon source & Nitrogen source \\
\hline Glucose & Yeast extract \\
Glucose & $\mathrm{CO}\left(\mathrm{NH}_{2}\right)_{2}$ \\
Glucose & $\left(\mathrm{NH}_{4}\right)_{2} \mathrm{SO}_{4}$ \\
Sucrose & Yeast extract \\
Sucrose & $\mathrm{CO}\left(\mathrm{NH}_{2}\right)_{2}$ \\
Sucrose & $\left(\mathrm{NH}_{4}\right)_{2} \mathrm{SO}_{4}$ \\
Fructose & Yeast extract \\
Fructose & $\mathrm{CO}\left(\mathrm{NH}_{2}\right)_{2}$ \\
Fructose & $\left(\mathrm{NH}_{4}\right)_{2} \mathrm{SO}_{4}$ \\
\hline
\end{tabular}

linear regression equation required to calculate the kojic acid content in each sample, and to find the value of $r$, seven different concentrations of kojic acid solution: 20.36, 40.72, 50.9, 61.08, 71.26, and 81.44 $\mathrm{\mu g}$ / $\mathrm{mL}$ were used to make the calibration curve. The seven kojic acid solutions were analyzed using TLC-densitometry at a wavelength of $318 \mathrm{~nm}$. The results were plotted against concentration to generate a calibration curve for kojic acid. Linear correlation uses the correlation coefficient $(r)$ in linear regression analysis, with an acceptance criterion of $r \geq 0.99908$. The calibration curve (Fig. 2) had the linear regression equation $y=89.352 x-435.55$, with $r$ correlation coefficient of 0.9993 . Therefore, the TLC-densitometry method of quantitative analysis of the kojic acid showed linearity.

\section{Accuracy and precision}

Accuracy and precision tests were performed by adding standards of known kojic acid concentration to samples of fermented filtrate. The kojic acid standards added were $80 \%, 100 \%$, and $120 \%$ of the amount of kojic acid in the sample. The result of the accuracy test was expressed as a percentage of recovery from the added analytes, while the precision test was expressed as the coefficient of variation.

The fermentation filtrate used in the accuracy and precision test used A. oryzae fermentation filtrate at a temperature of $35^{\circ} \mathrm{C}$. Since $1 \mathrm{~mL}$ of filtrate contained $0.7 \mathrm{mg}$ of kojic acid, $80 \%, 100 \%$, and $120 \%$ of kojic acid standard were calculated as the addition of $0.63 \mathrm{mg}, 0.73 \mathrm{mg}$, and $0.83 \mathrm{mg}$, respectively, of standard kojic acid.

The accuracy test gave an average range of the recovery rate from $98.68 \%$ to $100.88 \%$. For the precision test, the variation coefficient was obtained in the range of $1.16-5.84 \%$. Table 2 shows the data of the accuracy test result and complete precision.

The accuracy test met the criteria if the percentage recovery was within the range of $98-10 \%$, while the precision test met the criteria if the relative standard deviation value or coefficient of variation (CV) was $\leq 2 \%$ [8]. Based on this, the accuracy requirement for the percentage recovery of all concentration is in the range $98-102 \%$, while for precision, $80 \%$ concentration does not meet the requirements because the coefficient of variation is outside the range of $5.84 \%$.

The accuracy test met the criteria if the percentage recovery was within the range of $98-10 \%$, while the precision test met the criteria if the relative standard deviation value or CV was $\leq 2 \%$ [8]. Based on this, the accuracy requirement for the percentage recovery of all concentration is in the range $98-102 \%$, while for precision, $80 \%$ concentration does not meet the requirements because the coefficient of variation is outside the range of $5.84 \%$.

Table 2: Accuracy and precision test data for filtrate fermentation sample with standard addition of kojic acid

\begin{tabular}{|c|c|c|c|c|c|c|c|}
\hline Addition (\%) & $\begin{array}{l}\text { Addition of } \\
\text { standard (mg) }\end{array}$ & $\begin{array}{l}\text { Theoretical } \\
\text { mass (mg) }\end{array}$ & $\begin{array}{l}\text { Experimental } \\
\text { results area }(\mathrm{AU})\end{array}$ & $\begin{array}{l}\text { Experimental } \\
\text { results mass (mg) }\end{array}$ & Recovery (\%) & Average (\%) & $\begin{array}{l}\text { Coefficient of } \\
\text { variation (\%) }\end{array}$ \\
\hline \multirow[t]{6}{*}{80} & \multirow[t]{6}{*}{0.63} & \multirow[t]{6}{*}{1.37} & $10,985.9$ & 1.27825 & 93.30 & \multirow[t]{6}{*}{98.68} & \multirow[t]{6}{*}{5.84} \\
\hline & & & $12,288.3$ & 1.42401 & 103.94 & & \\
\hline & & & $11,363.1$ & 1.32047 & 96.38 & & \\
\hline & & & $12,015.7$ & 1.39351 & 101.72 & & \\
\hline & & & $12,449.5$ & 1.44206 & 105.26 & & \\
\hline & & & $10,764.3$ & 1.25345 & 91.49 & & \\
\hline \multirow{5}{*}{100} & \multirow{5}{*}{0.73} & \multirow{5}{*}{1.47} & $12,702.4$ & 1.47036 & 100.02 & \multirow{5}{*}{100.88} & \multirow{5}{*}{1.16} \\
\hline & & & $12,985.6$ & 1.50205 & 102.18 & & \\
\hline & & & $12,922.0$ & 1.49494 & 101.70 & & \\
\hline & & & $12,861.4$ & 1.48815 & 101.23 & & \\
\hline & & & $12,565.5$ & 1.45504 & 98.98 & & \\
\hline \multirow[t]{5}{*}{120} & \multirow[t]{5}{*}{0.83} & \multirow[t]{5}{*}{1.57} & $13,484.5$ & 1.55789 & 99.23 & \multirow[t]{5}{*}{100.16} & \multirow[t]{5}{*}{1.30} \\
\hline & & & $13,587.5$ & 1.56942 & 99.96 & & \\
\hline & & & $13,490.2$ & 1.55853 & 99.27 & & \\
\hline & & & $13,903.6$ & 1.60479 & 102.22 & & \\
\hline & & & $13,768.2$ & 1.58964 & 101.25 & & \\
\hline
\end{tabular}


Table 3: Determination of kojic acid content and dry cell weight for fermentation filtrate optimization of carbon and nitrogen source

\begin{tabular}{lllll}
\hline $\begin{array}{l}\text { Carbon source } \\
\mathbf{5 0} \mathbf{g} / \mathbf{L})\end{array}$ & $\begin{array}{l}\text { Nitrogen source } \\
\mathbf{( 2 . 5} \mathbf{g} / \mathbf{L})\end{array}$ & $\begin{array}{l}\text { Acquired } \\
\text { area }(\mathbf{A U})\end{array}$ & $\begin{array}{l}\text { Kojic acid } \\
\mathbf{( g / L )}\end{array}$ & $\begin{array}{l}\text { Dry cell } \\
\text { weight } \mathbf{( g / L )}\end{array}$ \\
\hline Glucose & Yeast extract & 5163.8 & 0.6267 & 13.824 \\
Glucose & $\mathrm{CO}\left(\mathrm{NH}_{2}\right)_{2}$ & undetected & - & 8.776 \\
Glucose & $\left(\mathrm{NH}_{4}\right)_{2} \mathrm{SO}_{4}$ & 3859.4 & 0.4807 & 10.638 \\
Sucrose & $\mathrm{Yeast} \mathrm{extract}_{\text {Sucrose }}^{\mathrm{CO}\left(\mathrm{NH}_{2}\right)_{2}}$ & $13,168.4$ & 1.5245 & 14.147 \\
Sucrose & $\left(\mathrm{NH}_{4}\right)_{2} \mathrm{SO}_{4}$ & 2379.0 & 0.3150 & 11.082 \\
Fructose & $\mathrm{Yeast} \mathrm{extract}_{\text {Fructose }}^{\mathrm{CO}\left(\mathrm{NH}_{2}\right)_{2}}$ & 5349.3 & 0.6474 & 14.253 \\
Fructose & $\left(\mathrm{NH}_{4}\right)_{2} \mathrm{SO}_{4}$ & 786.7 & 0.1368 & 12.395 \\
& & 2630.5 & 0.3431 & 11.154 \\
\hline
\end{tabular}

Quantitative analysis of fermentation culture

In the present study, the fermentation medium was optimized, focusing on the carbon and nitrogen sources as well as $\mathrm{pH}$ followed by optimization of aeration and incubation temperature. Quantitative analysis of the biomass and kojic acid was produced for the results of each culture condition. The dry cell weight method was used to perform the biomass analysis, while TLC-densitometry was used to analyze the kojic acid.

\section{Optimization of the carbon and nitrogen sources}

To determine the type of carbon and nitrogen to be used in the next stage of fermentation optimization, the carbon and nitrogen sources were optimized first. Glucose, sucrose, and fructose were selected as carbon sources while yeast extract, urea, and ammonium sulfate were used as nitrogen sources.

The dry cell weight yield indicated that, in general, fermentation culture using sucrose as a carbon source gave the highest average dry cell weight compared with other carbon sources. The mean dry cell weight for fermentation culture with sucrose as a carbon source was $12.669 \mathrm{~g} / \mathrm{L}$, but this only reached 10.807 and $10.349 \mathrm{~g} / \mathrm{L}$ for glucose and fructose, respectively. Optimization of the nitrogen source in the medium showed that fermentation culture using yeast extract gave the highest average dry cell weight of $12.919 \mathrm{~g} / \mathrm{L}$ compared with urea and ammonium sulfate that gave $10.138 \mathrm{~g} / \mathrm{L}$ and $10.767 \mathrm{~g} / \mathrm{L}$, respectively. Table 3 shows that the largest dry cell weight $(14.417 \mathrm{~g} / \mathrm{L})$ was seen with fermentation culture using sucrose as the carbon source and yeast extract as the nitrogen source (condition no. 4), while the smallest yield was $8.192 \mathrm{~g} / \mathrm{L}$, using fructose as a carbon source and ammonium sulfate as a source of nitrogen (condition no. 9).

\section{Optimization of $\mathbf{p H}$}

Next, we optimized the pH used for fermentation. The acidity level was adjusted by adding a few drops of $1 \mathrm{~N} \mathrm{HCl}$ into the fermentation medium until the desired $\mathrm{pH}$ was obtained. The optimization used $\mathrm{pH} 3.5,4.5$, and 5.5. Table 4 shows the results for the dry cell weight and total kojic acid content.

\section{Aeration optimization}

Aeration optimization was performed using four different volumes, 50, 100,125 , and $150 \mathrm{~mL}$, in a $250 \mathrm{~mL}$ conical flask. Table 5 shows the data for the dry cell weight and total kojic acid.

\section{Temperature optimization}

Finally, the temperature was optimized by applying all the fermentation conditions obtained in the previous stages. Two temperature variations were performed: The first fermentation was carried out at room temperature in the fungus incubation room located on the third floor of the Faculty of Pharmacy University of Indonesia, with a mean temperature of approximately $30^{\circ} \mathrm{C}$ (range, $28-32^{\circ} \mathrm{C}$ ). The second fermentation was carried out in a temperature-regulated incubator set at $35^{\circ} \mathrm{C}$.

The results showed that fermentation at room temperature yielded a higher dry cell weight than fermentation at $35^{\circ} \mathrm{C}$; however, fermentation at $35^{\circ} \mathrm{C}$ yielded higher kojic acid levels (Table 6).
Table 4: Kojic acid and dry cell weight of medium pH for optimization of fermentation culture

\begin{tabular}{llll}
\hline pH & $\begin{array}{l}\text { Acquired } \\
\text { area (AU) }\end{array}$ & $\begin{array}{l}\text { Kojic } \\
\text { acid }(\mathrm{g} / \mathrm{L})\end{array}$ & $\begin{array}{l}\text { Dry cell } \\
\text { weight } \mathbf{( g / L )}\end{array}$ \\
\hline 3.5 & $12,961.5$ & 1.4994 & 13.603 \\
4.5 & $14,868.1$ & 1.7127 & 14.772 \\
5.5 & 8117.3 & 0.9572 & 14.015 \\
\hline
\end{tabular}

Table 5: Kojic acid concentration and dry cell weights for aeration optimization

\begin{tabular}{llll}
\hline $\begin{array}{l}\text { Volume } \\
(\mathbf{m L})\end{array}$ & $\begin{array}{l}\text { Acquired } \\
\text { area }(\mathbf{A U})\end{array}$ & $\begin{array}{l}\text { Kojic acid } \\
\mathbf{( g / L )}\end{array}$ & $\begin{array}{l}\text { Dry cell } \\
\text { weight }(\mathrm{g} / \mathbf{L})\end{array}$ \\
\hline 50 & $14,011.6$ & 1.6169 & 13.542 \\
100 & $14,282.7$ & 1.6472 & 12.077 \\
125 & 9767 & 1.1418 & 11.805 \\
150 & 6022.1 & 0.7227 & 11.594 \\
\hline
\end{tabular}

Table 6: Kojic acid concentration and dry cell weight of fermentation optimization temperature culture

\begin{tabular}{llll}
\hline $\begin{array}{l}\text { Incubation } \\
\text { Temperature }\left({ }^{\circ} \mathrm{C}\right)\end{array}$ & $\begin{array}{l}\text { Acquired } \\
\text { area }(\mathrm{AU})\end{array}$ & $\begin{array}{l}\text { Kojic acid } \\
\mathbf{( g / L )}\end{array}$ & $\begin{array}{l}\text { Dry cell } \\
\text { weight }(\mathrm{g} / \mathrm{L})\end{array}$ \\
\hline 30 & 5338.5 & 0.6462 & 8.552 \\
35 & 6157 & 0.7378 & 8.057 \\
\hline
\end{tabular}

\section{Determination of sugar content in fermentation filtrate}

The remaining sugar content in the filtrate was determined using sucrose as the selected carbon source. The analysis was performed using phenol sulfate and ultraviolet-visible spectrophotometry at wavelength of $490 \mathrm{~nm}$ [11].

After generating the calibration curve, the remaining sucrose content still presents in each sample was calculated. The sucrose concentration was measured using the fermentation filtrate from the optimization result that showed the highest kojic acid content, the optimum medium $\mathrm{pH} 4.5$, and an incubation temperature of $35^{\circ} \mathrm{C}$. The samples predicted to have a high absorption were diluted 1 in 1000 .

\section{Fermentation efficiency}

The amount of product produced compared with the amount of the initial substrate used is known as the yield value (Yp/s). Tables 7 and 8 show the yield data for fermentation.

\section{Discussion}

Rejuvenation and inoculum preparation

The A. oryzae cultures obtained from Institut Pertanian Bogor Culture Collection were stored in the refrigerator to keep the culture dormant. To reactivate the culture for use in the preparation of the inoculum, rejuvenation of the cultures was performed in tilted tubes containing 
PDA every 2 months for stock cultures, and 2 weeks for working cultures.

After incubation for $24 \mathrm{~h}$ at $180 \mathrm{rpm}$, the precultured form of pelletized A. oryzae cell biomass was yellowish-white. Throughout the study, precultures were used for each fermentation experiment. Fig. 2 shows there was a difference in the amount of biomass formed at the first preculture, conducted on March 27, 2017 (Fig. 2a), compared with the last preculture, conducted on May 27, 2017 (Fig. 2b), although both used the same medium with the same incubation conditions. The first preculture formed a greater amount of cell biomass compared with the last preculture. This may have been due to the age of the $A$. oryzae culture used in the inoculum preparation process. This is in accordance with previous studies that suggested that the age of the culture used to make a spore suspension in the preparation of inoculum has an effect on the preculture and fermentation [2].

Verification of kojic acid analysis method using TLC-densitometry For the precision test, $80 \%$ concentration was not fulfilled because the coefficient of variation was outside the range of $5.84 \%$. This may have been due to technical errors of implementation, such as at the time of bottling and elution that may have affected the repetition of levels obtained.

\section{Quantitative analysis of the fermentation culture \\ Optimization of the carbon and nitrogen source}

The determination of kojic acid levels using nine fermentation filtrates showed that the most significant difference between the highest concentration of kojic acid (1.5425 g/L) was obtained from filtrate no. 4 compared with the other filtrates. The results of dry cell weight and kojic acid content showed that medium containing $5 \%$ sucrose as a carbon source and $2.5 \%$ yeast extract as a nitrogen source produced the greatest biomass and kojic acid content. Unlike dry cell weights, the resulting kojic acid content was not only seen based on the carbon or nitrogen source alone but also on the physical and chemical properties of the combined carbon and nitrogen source used.

\section{Optimum pH}

Our results showed that both dry cell weight and the highest kojic acid content were produced by fermentation using the medium at $\mathrm{pH} 4.5$, yielding $14.772 \mathrm{~g} / \mathrm{L}$ dry cell weight, and $1.7127 \mathrm{~g} / \mathrm{L}$ kojic acid. The

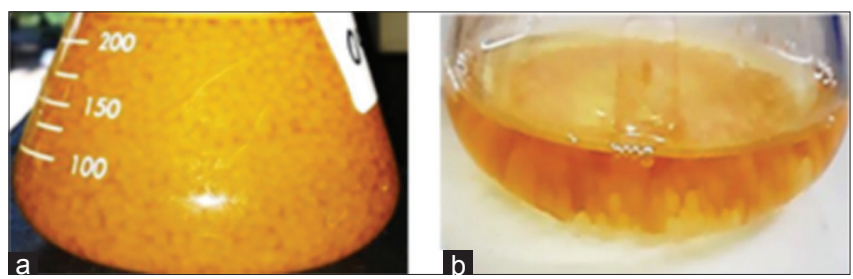

Fig. 2: (a and b) Preculture of Aspergillus oryzae after $24 \mathrm{~h}$

Table 7: Determination of sucrose content in filtrate fermentation

\begin{tabular}{lllll}
\hline $\begin{array}{l}\text { Culture } \\
\text { condition }\end{array}$ & $\begin{array}{l}\text { Substrate } \\
\text { levels (g/L) }\end{array}$ & Dilution & Absorbance & $\begin{array}{l}\text { Sucrose } \\
\text { levels (g/L) }\end{array}$ \\
\hline $\mathrm{pH} 4.5$ & 50 & $1000 \times$ & 0.218 & 3.5510 \\
$35^{\circ} \mathrm{C}$ & 50 & $1000 \times$ & 0.404 & 6.5127 \\
\hline
\end{tabular}

acidity level affects the function as well as the structure of the enzymes that play a role in the fermentation process. Production of kojic acid by fermentation increases with acidity, but acidity that is too strong can inhibit mold growth. However, this does not affect kojic acid fermentation using A. oryzae, since the optimal $\mathrm{pH}$ is highly dependent on the carbon and nitrogen source used [1].

\section{Aeration optimization}

The results showed the highest dry cell weight (13.542 g/L) using a volume of $50 \mathrm{~mL}$, while the highest kojic acid content $(1.6472 \mathrm{~g} / \mathrm{L})$ was produced by fermentation with a volume $100 \mathrm{~mL}$. Kojic acid fermentation is aerobic; therefore, aeration is an important factor. Our results showed a decrease in dry cell weight formed when a smaller cavity remained in the conical flask. Higher amounts of oxygen in the $50 \mathrm{~mL}$ medium caused more mold to grow. While using a volume of $100 \mathrm{~mL}$, cell growth was not as great as with $50 \mathrm{~mL}$; however, the resulting kojic acid content was higher. This is because, with a volume of $50 \mathrm{~mL}$, the substrate is used for cell growth rather than being converted into kojic acid. Fermentation using more than $100 \mathrm{~mL}$ of medium shows a decrease in dry cell weight, as well as the kojic acid level because the amount of available oxygen is not able to meet the demands of mold.

\section{Temperature optimization}

Our results showed that molds grow better grown at room temperature; however, the production of kojic acid was higher in the cultures incubated at $35^{\circ} \mathrm{C}$. It was also noted that the average dry cell weight and kojic acid levels produced during temperature optimization were much lower than with the aeration optimization. This could have been caused by the quality of the inoculum or the preculture used for fermentation because the production of kojic acid and dry weight is influenced by the age of the culture used during the preparation of the inoculum, as well as the size of the inoculum [2].

\section{Sugar levels in the fermentation filtrate}

During fermentation, microbes convert the carbon source into cell biomass, and production of the product decreases the concentration of the carbon source in the medium. The total sugar remaining during fermentation was calculated to determine the total sugar left in the fermentation medium to measure mold productivity by comparing the amount of sugar consumed with the amount of product. The resulting glucose level in the fermentation filtrate was optimum at $\mathrm{pH} 4.5$ and contained less glucose than the fermentation filtrate incubated at $35^{\circ} \mathrm{C}$. This shows that the $\mathrm{pH}$ of the medium has a greater influence on glucose consumption by A. oryzae than the incubation temperature.

\section{Fermentation efficiency}

Based on the results shown in Table 8, fermentation of kojic acid using $A$. oryzae during the $\mathrm{pH}$ medium optimization stage showed a greater yield $(0.0370 \mathrm{~g} / \mathrm{g})$ compared with fermentation performed at the temperature optimization stage $(0.0170 \mathrm{~g} / \mathrm{g})$. These results show that the $\mathrm{pH}$ of the medium influences the fermentation efficiency to a greater extent than temperature. The efficiency of fermentation at each stage of fermentation increased due to previous conditions that were more optimal. This may be due to a decline in the quality or condition of mold culture shown by decreased mold growth in the rejuvenation and preparation of the previous inoculum performed.

\section{CONCLUSION}

The optimal medium for fermentation of kojic acid using $A$. oryzae uses sucrose and yeast extract as carbon and nitrogen sources, respectively, at $\mathrm{pH}$ 4.5. The optimal aeration and incubation conditions were used a

Table 8: Yield from the fermentation optimization results

\begin{tabular}{lllllll}
\hline $\begin{array}{l}\text { Culture } \\
\text { condition }\end{array}$ & $\begin{array}{l}\text { Initial substrate } \\
\text { level (g/L) }\end{array}$ & $\begin{array}{l}\text { Sucrose } \\
\text { (g/L) }\end{array}$ & $\begin{array}{l}\text { Sucrose } \\
\text { consumed (\%) }\end{array}$ & $\begin{array}{l}\text { Sucrose } \\
\text { consumed (g/L) }\end{array}$ & $\begin{array}{l}\text { Kojic acid } \\
\text { (g/L) }\end{array}$ & $\begin{array}{l}\text { Yield } \\
\text { (g/g) }\end{array}$ \\
\hline $\mathrm{pH} 4.5$ & 50 & 3.5510 & 92.9 & 46.449 & 1.7127 & 0.0370 \\
$35^{\circ} \mathrm{C}$ & 50 & 6.5127 & 86.97 & 43.4873 & 0.7378 & 0.0170 \\
\hline
\end{tabular}


volume of $100 \mathrm{~mL}$ in a $250 \mathrm{~mL}$ conical flask, incubated at $35^{\circ} \mathrm{C}$, obtaining the highest yield value of $0.0370 \mathrm{~g} / \mathrm{g}$.

\section{CONFLICTS OF INTEREST}

All authors have none to declare.

\section{REFERENCES}

1. Rosfarizan M, Shamzi M, Nurashikin S, Madihah MS, Arbakariya AB. Kojic acid: Applications and development of fermentation process for production. Biotechnol Mol Biol R 2010;5:24-37.

2. Hassan H, Saad A, Hazzaa M, Ibrahim E. Optimization study for the production of kojic acid crystals by Aspergillus oryzae var. effusus NRC 14 isolate. Int J Curr Microbiol Appl Sci 2014;3:133-42.

3. Sauriasari R, Azizah N, Basah K. Tyrosinase inhibition, 2-2- diphenyl-1-picrylhydrazyl radical scavenging activity, and phtochemical screening of fractions and ethanol extract from leaves and stem bark of matoa (Pometia pinnata). Asian J Pharm Clin Res 2017;10:85-9.

4. Mukul S, Surabhi K, Atul N. Cosmeceutical for the skin: An overview.
Asian J Pharm Clin Res 2011:4:1-6.

5. Piantavini MS, Goncalves AG, Trindade AC, Merce AL, Pontarolo R. Development and validation of a UV spectrophotometric method for kojic acid quantification based on its aluminum complexes. Asian J Pharm Clin Res 2013;6:70-3.

6. Shurtleff W, Aoyagi A. History of Soy Sauce (160 CE to 2012). Lafayette, (CA): Soyinfo Center; 2012.

7. Kulp K, Ponte J. Handbook of Cereal Science and Technology. New York: Marcel Dekker; 2000

8. El-Aziz AB. Improvement of kojic acid production by a mutant strain of Aspergillus flavus. J Nat Sci Res 2013;3:31-41.

9. Mirantini A. Isolation, Purification, and Chemical Characterization of Kojic Acid Produced by the Aspergillus flavus Mutant Strain M3B7F7E8. Depok: Universitas Indonesia; 2007.

10. Suryadi H, Radji M, Dianingtyas J, Hidayah A. Improvement of Kojic Acid Production by a Mutant Strain of Aspergillus flavus, N40C10. Bandung, Indonesia: International Conference of Mathemathics and Natural Sciences; 2006.

11. Dubois M, Gilles KA, Hamilton JK, Rebers PA, Smith F. Colorimetric method for determination of sugars and related substances. Anal Chem 1956;28:350-6. 